\title{
Investigation of the effects of drugs effective on PI3K-AKT signaling pathway in colorectal cancer alone and in combination
}

\author{
Kolorektal kanserde PI3K-AKT sinyal yolağı üzerinden etki gösteren ilaçların \\ tek başlarına ve kombinasyonlarının etkilerinin araştırılması
}

\author{
Tijen Kaya Temiz, Ahmet Altun, Nergiz Hacer Turgut*, Ezgi Balcı
}

Department of Pharmacology (Prof. T. T. Kaya, MD), İzmir Katip Çelebi University School of Medicine, TR-35620 İzmir. Department of Pharmacology (Assist. Prof. A. Altun, MD, Assist. Prof. N. H. Turgut, MD, E. Balc1, MD), Cumhuriyet University School of Medicine, TR-58140 Sivas.

\begin{abstract}
Aim. This study was designed to determine the agent and/or possible agent combinations that may be effective in the treatment of colorectal cancer. For this reason the single and combined antiproliferative effects of NVPBEZ-235, API-1, LY 294002 and PP242 which target PI3K/AKT pathway well known to have an important role in pathophysiological mechanisms of colorectal cancer were investigated. We investigated whether NVPBEZ-235, API-1 and PP242 have antiproliferative effects which have not been studied on this cancer type and also compared the effects with LY294002 known to have antiproliferative effect on colorectal cancer. Method. DLD1 cell line was used as colorectal cells. Real time cell analysis (xCELLigence system) was used to determine the effects of the agents in colorectal cell proliferation. Results. When the agents were applied alone, PI3K/mTOR dual inhibitor NVP-BEZ had the strongest cytotoxic effect and PI3K inhibitor LY294002 had the lowest cytotoxic effect. None of the combinations were not superior compared to alone applications. Conclusion. This study indicates that when PI3K/AKT pathway is targeted, instead of combined treatment, targeted specific treatment with a single agent having higher affinity and effectiveness would be more appropriate. Also among the agents effecting PI3K/AKT pathway especially, NVP-BEZ for targeted therapy can be alternative to conventional treatments.
\end{abstract}

Keywords: Colorectal cancer, PI3K/AKT pathway, NVPBEZ-235, API-1, LY 294002, PP242

\section{Özet}

Amaç. $\mathrm{Bu}$ çalışma kolorektal kanser tedavisinde etkili madde ve/veya olası madde kombinasyonlarını belirlemek için tasarlanmıştır. Bu nedenle kolorektal kanserin patofizyolojik mekanizmalarında önemli bir rol oynadığı bilinen PI3K/Akt yolağını hedef alan NVPBEZ-235, API-1, LY 294002 ve PP242'nin tek ve kombinasyon halinde anti-proliferatif etkileri araştırıldı. Daha önce bu kanser tipinde çalışılmayan NVPBEZ-235, API-1 ve PP242'nin anti-proliferatif etkilerinin olup olmadığı araştırıldı. Ayrıca bu etkileri kolorektal kanser üzerinde anti-proliferatif bir etkiye sahip olduğu bilinen LY 294002 ile karşılaştırıldı. Yöntem. DLD-1 hücre hattı kolorektal hücre olarak kullanıldı. Gerçek zamanlı hücre analizi (XCELLigence sistemi) kolorektal hücre çoğalmasında ajanların etkilerini belirlemek için kullanıldı. Bulgular. Maddeler tek başına uygulandığı zaman NVPBEZ-235, dual PI3K/mTOR inhibitörü NVP-BEZ en güçlü sitotoksik etkiye ve PI3K inhibitörü LY294002 en düşük sitotoksisiteye sahipti. Kombinasyonların hiçbiri, tek başına uygulamaları ile karşılaştırıldığında daha üstün değildi. Sonuç. Bu çalışma PI3K/Akt yolağı hedef alındığında, kombine tedavi yerine daha yüksek afinitesi ve etkinliği olan tek bir madde ile hedefe yönelik spesifik tedavinin daha uygun olacağını göstermektedir. Ayrıca özellikle PI3K/Akt yolağını etkileyen maddeler arasında NVP-BEZ hedefe yönelik tedavide geleneksel tedaviler için bir alternatif olabilir.

Anahtar sözcükler: Kolorektal kanser, PI3K/AKT yolağı, NVPBEZ-235, API-1, LY 294002, PP242 
Geliş tarihi/Received: May 19, 2014; Kabul tarihi/Accepted: June 04, 2014

\section{*Corresponding author:}

Dr. Nergiz Hacer Turgut, Farmokoloji Anabilim Dalı, Cumhuriyet Üniversitesi Tıp Fakültesi, TR58140 Sivas. E-mail: nergizht@yahoo.com

\section{Introduction}

Colorectal cancer (CRC) is one of the most common type of cancer and leading death of cancer worldwide [1]. Both genetic and environmental factors are involved in the carcinogenesis of CRC. It takes a long time for the CRC to develop and the development proceeds from polyps to adenocarcinoma [2,3]. Despite recent progresses in the treatment protocols for $\mathrm{CRC}$, the underlying mechanisms regulating the growth and advancement of CRC are not completely known. Cellular functions like cell growth, proliferation and cell survival are regulated by signal transduction pathways. Understanding the signaling pathways better which are responsible for these processes will ease development of new treatment strategies and increase patient survival. Each cancer is particularly affected by a specific signal transduction pathway and this pathway is modified by carcinogenic micro-environmental factors or accumulation of gene mutation [4]. Colorectal cancer is intimately associated with PI3K/Akt signal pathway. Inhibiting this pathway maintains a therapeutic approach which may entail to curable CRC $[5,6]$.

PI3K/Akt is an important intracellular pathway which has been studied in recent years. PI3K is a heterodimeric molecule, with regulatory and catalytic subunits. According to catalytic subunit differences it has alpha, beta, gamma and delta subunits [7]. Akt is a downstream effector of PI3K and the effects of PI3K on tumor growth and progression are thought to be mediated by Akt, a serine/threonine protein kinase (Ser/Thr kinase) [8]. It has been reported that in human CRCs, Akt phosphorylation associates with cell proliferation and apoptosis inhibition $[9,10]$. As the activation of the PI3K/Akt pathway has been shown to be responsible for carcinogenesis and metastasis of many cancers, the inhibition has been used for cancer treatment and many molecules are being developed for this objective $[5,6]$.

PI3/Akt also increases protein synthesis and cell size by activating mTOR (mammalian target of rapamycin), mTOR is a conserved Ser/Thr kinase which is a component of intracellular signaling for cellular growth, mRNA translation, and metabolism [11]. It has been suggested that mTOR plays an important role in the carcinogenesis of many cancers $[12,13]$.

The objective of this study was to investigate the effects of NVP-BEZ 235 (PI3K and mTOR inhibitor), API-1 (selective AKT/proteinkinase B (PKB) inhibitor) and PP242 (selective mTOR inhibitor) which have not been studied for CRC before, alone and in combination and also to compare these effects with LY294002 (selective PI3K inhibitor) an agent which its' effectiveness has been shown for colon cancer $[14,15]$. Therefore our goal is to determine the agent and/or possible agent combinations affecting that PI3K/Akt pathway that may be effective in the treatment of CRC.

\section{Materials and methods}

NVP-BEZ 235, API-1, PP242 and LY294002 were purchased from LC Laboratories, Woburn, MA, USA. All medium, solution and enzymes for cell culture were purchased from Sigma Aldrich. 


\section{Cell Culture}

Human colon cancer cells DLD-1 were purchased from the Sap Institute (The Ministry of Food, Agriculture and Livestock, Ankara, Turkey). Cells were multiplied in three passages, frozen in aliquots and stored in liquid nitrogen. The cells were maintained in DMEM with phenol red and NaHCO3. The culture medium was supplemented with $10 \%$ heat inactivated FBS, $\% 1$ penicillin and streptomycin. Cells were grown in T-75 cm2 culture flasks in a humidified atmosphere containing 5\% $\mathrm{CO} 2$ at $37 \mathrm{oC}$.

\section{Instrumentation \\ xCELLigence system}

The xCELLigence system was used according to the instructions of the supplier [16]. The xCELLigence system consists of four main components: The RTCA analyzer, the RTCA DP station, the RTCA computer with integrated software, and disposable E-plate 16. The RTCA DP station fits inside a standard tissue-culture incubator, while an analyzer and laptop computer with software will be on the outside. The core of the xCELLigence system is the E-plate 16: This is a single use, disposable device used for performing cellbased assays on the RTCA DP instrument, which has similar application like commonly used 96-well micro titer plate. However the E-plate 16 differs from standard 96-well micro titer plates vastly with its incorporated gold cell sensor arrays in the bottom, which contributes cells in-side each well to be monitored and assayed. The E-plate 16 has a low evaporation lid design; the bottom diameter of each well is $5.0 \mathrm{mM} \pm 0.05 \mathrm{mM}$; with a total volume of $210 \pm 5 \mu \mathrm{L}$, approximately $80 \%$ of the bottom areas of each well is covered by the circle-on-line electrodes, which is designed to be used in an environment of +15 to $+40^{\circ} \mathrm{C}$, relative humidity $98 \%$ maximum without condensation. The electronic impedance of sensor electrodes is measured to allow monitoring and detection of physiological changes of the cells on the electrodes. The voltage applied to the electrodes during RTCA measurement is about $20 \mathrm{mV}$ (RMS). The impedance measured between electrodes in an individual well depends on electrode geometry, ion concentration in the well and whether or not cells are attached to the electrodes. In the absence of cells, electrode impedance is mainly determined by the ion environment both at the electrode/solution interface and in the bulk solution. In the presence of cells, cells attached to the electrode sensor surfaces will act as insulators and thereby alter the local ion environment at the electrode/solution interface, leading to an increase in impedance. Thus, when more cells are growing on the electrodes, the larger is the value of electrode impedance. The RTCA associated software allows users to obtain parameters such as: Average value, maximum and minimum values, standard deviation (SD), half maximum effect of concentration (EC50), half maximum inhibition of concentration (IC50), cell index (CI), and in addition graphics. The data expressed in CI unit scan is exported to Excel for any type of mathematical analysis [16].

\section{Cell growth and proliferation assay using $x$ CELLigence system}

DLD-1 cells were grown and expanded in tissue-culture flasks. After reaching $\sim 75 \%$ confluences, the DLD-1s were washed with PBS and detached from the flasks by treatment with trypsin/EDTA. Afterwards, $100 \mu \mathrm{L}$ of cell culture media at room temperature was added into each well of E-plate16. Then the Eplate16 was connected to the system and checked in the cell culture incubator for proper electrical contacts and the background impedance was measured. Meanwhile, the cells were resuspended in cell culture medium and adjusted to 40.000 cells $/ \mathrm{mL}$. $100 \mu \mathrm{L}$ of cell suspension was added to the $100 \mathrm{KL}$ medium containing wells on E-plate16. After $30 \mathrm{~min}$ incubation at room temperature, E-plate16 was placed into the cell culture incubator. Finally, proliferation of the cells was monitored every hour for a period of up to $72 \mathrm{~h}$ via the incorporated sensor electrode arrays of the E-Plate16. The electrical impedance was measured by the RTCAintegrated software of the xCELLigence system as a dimensionless parameter termed CI. 


\section{Cytotoxicity assay using xCELLigence system}

For proliferation experiments the optimal seeding concentration of the DLD-1 was determined. After seeding the respective number of cells in $100 \mu \mathrm{L}$ medium to each well of the E-plate16, the proliferation of the cells was monitored every $30 \mathrm{~min}$ by the xCELLigence system. Approximately $18 \mathrm{~h}$ after seeding, when the cells were in the log growth phase, the cells were exposed to $10 \mu \mathrm{L}$ of medium containing the NVP-BEZ 235 $(500,250,125,62.5,31.25,15.62,7.81,1.95$ and $0.48 \mathrm{nM} /$ well $)$, API-1 (240,120,60, $30.15,7.5,3.7,0.93,0.46$ and $0.23 \mathrm{mM} /$ well $), \mathrm{LY} 294002(20,10,5,2.5,1.25 \mathrm{mM} /$ well $)$ and PP242 (80, 40, 20, 10,5, 2.5, 1.25, 0.62, 031, 015, 0.07 and $0.03 \mathrm{mM} /$ well) both alone and in combination. Controls received either medium only, or medium+NVP-BEZ 235 or medium+API-1 or medium+LY294002 or medium+PP242. All experiments were run for $72 \mathrm{~h}$.

\section{Statistical analysis}

The scores of angiogenesis were compared with Kruskal-Wallis ANOVA test and MannWhitney U test. A p value of less than 0.05 was considered as statistically significant.

\section{Results}

\section{Monitoring dynamic cell proliferation and attachment in real-time using xCELLigence system}

To determine the optimal concentration for cell proliferation and viability measurements; $100.000,50.000,25.000,12.500,6.250,3.125$ and 1.562 cells/well were seeded in the EPlate 16 and the impedance was determined. The impedance CI of $100.000,50.000$, $25.000,12.500,6.250,3.125$ and 1.562 cells/well increased proportionally to cell number (Figure 1). The CI of each cell concentration sharply increased after seeding up to reach its maximum at $2.5 \mathrm{~h}$ as shown in Figure 1. Then the CI of 50.000 cells/well slowly decreased to reach a minimum at $7 \mathrm{~h}$ to increase again to a maximum at $19 \mathrm{~h}$. The response seen in the 12.500-50.000 cells/well experiments reflects cell cycle effects, while the concentration of 100.000 cells/well was not suited for further experimentation, possibly because of a too high cell density and the resulting contact inhibition.

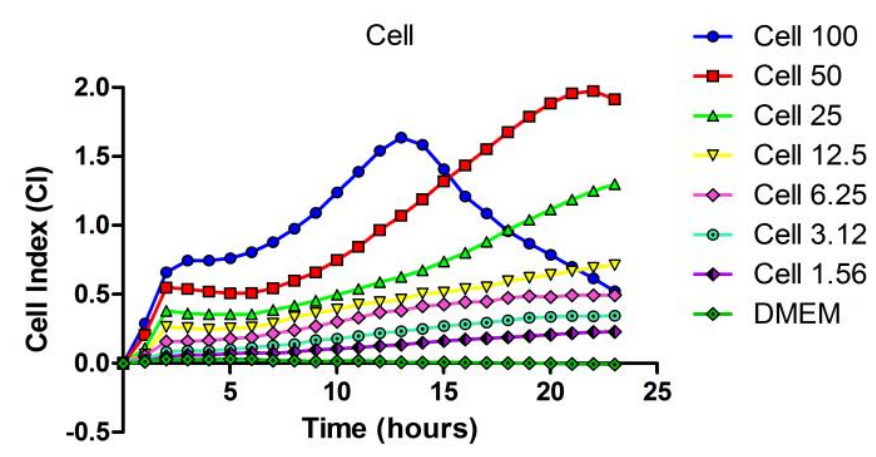

Figure 1. Dynamic monitoring of cell proliferation using xCELLigence system. DLD-1 cells seeded at a density of 100.000, 50.000, 25.000, 12.500, 6.250, 3.125 and 1.562 cells per well in E-plates 16 were observed during $24 \mathrm{~h}$. The legend on the right indicates the number of cells x 1000 .

\section{Monitoring of cytotoxicity of agents alone in real-time using xCELLigence system NVP-BEZ 235 administration alone}

We used the 50,000 cells/well concentration in the xCELLigence assay to examine the anti-proliferative effects revealed by NVP-BEZ 235. In order to assess the anti-tumoral effect of NVP-BEZ 235 on DLD-1 cells; 500, 250, 125, 65.2, 31.25, 15.62, 7.81, 1.95 and $0.48 \mathrm{nM}$ concentrations were used. NVP-BEZ 235 treated DLD-1 cells showed 
decreasing cell index values in a concentration dependent manner. Cells continued proliferation up to 24 hour and cell index raised up to 1 . After the drug administration at 24th hour, the cytotoxic effect was followed up to 48th hour with hourly measurements. While 500, 250 and $125 \mathrm{nM}$ showed complete cytotoxic effect and decreased CI to 0.1, $62.5 \mathrm{nM}$ decreased CI to 0.4 and caused partial cell death. These showed statistically significant cytotoxic effect when compared to the control $(\mathrm{p}<0.05)$. Other concentrations had no effect on DLD-1 cells (Figure 2A). Twenty-four hours after treatment with NVPBEZ 235, an inhibitor concentration 50 value of (IC50) 6.2x10-8 M and curve fit value of Square $\mathrm{R}=0.999$ was achieved (Figure 3).

\section{API-1 administration alone}

To evaluate the anti-tumoral effect of API-1 on DLD-1 cells; 240, 120, 60, 30.15, 7.5, $3.7,0.93,0.46$ and $0.23 \mathrm{mM}$ concentrations were used. The effect on cell proliferation was evaluated by Xcelligence system. API-1 treated DLD-1 cells exhibited decreasing cell index values in a concentration dependent manner. Cells continued proliferation up to 12 hour and cell index raised up to 1. After the drug administration at 12th hour, the cytotoxic effect was followed up to 24th hour with hourly. While 240, 120 and $60 \mathrm{mM}$ showed complete cytotoxic effect; $15 \mathrm{mM}$ and $7.5 \mathrm{mM}$ caused partial cell death (Figure 2B). For API-1 an IC50 value of 16.2x10-8 and curve fit value of Square R=0.927 was calculated (Figure 3).

\section{LY294002 administration alone}

To evaluate the anti-tumoral effect of LY294002 on DLD-1 cells; 20, 10, 5, 2.5 and 1.25 $\mathrm{mM}$ concentrations were used. The effect on cell proliferation was evaluated by Xcelligence system. LY294002 treated DLD-1 cells exhibited decreasing cell index values in a concentration dependent manner. Cells continued proliferation up to 24 hour and cell index raised up to 5. After the drug administration at 24th hour, the cytotoxic effect was followed up to 48th hour with hourly. While $20 \mathrm{mM}$ concentration showed a significant cytotoxic effect $(\mathrm{p}<0.05)$, other concentrations showed no statistically significant difference when compared to the control (Figure 2C). For LY294002 an IC50 value of 1.99x10-7 and curve fit value of Square R=0.714 was calculated (Figure 3).

\section{PP242 administration alone}

To evaluate the anti-tumoral effect of PP242 on DLD-1 cells; 80, 40, 20, 10, 5, 2.5, 1.25, $0.62,0.31,0.15,0.07$ and $0.03 \mathrm{mM}$ concentrations were used. The effect on cell proliferation was evaluated by Xcelligence system. PP242 treated DLD-1 cells exhibited decreasing cell index values in a concentration dependent manner. Cells continued proliferation up to 12th hour and cell index raised up to 1 . After the drug administration at 12th hour, the cytotoxic effect was followed up to 24th hour with hourly. While 80 and $40 \mathrm{mM}$ concentrations showed complete cytotoxic effect and decreased CI to $0.1 ; 20$ and $10 \mathrm{mM}$ only showed a partial cell death of $50 \%$. These showed statistically significant cytotoxic effect when compared to the control $(\mathrm{p}<0.05)$. Other concentrations showed no statistically significant difference when compared to the control (Figure 2D). For PP242 an IC50 value of 8.19x10-8 and curve fit value of Square R=0.914 was calculated (Figure $3)$. 

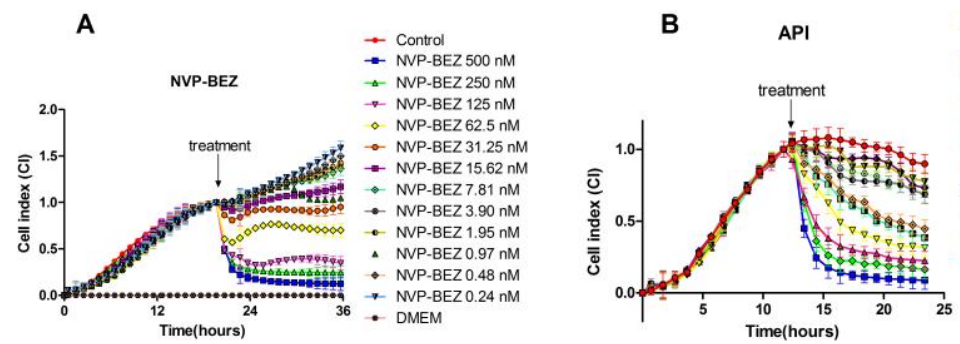

- API $240 \mathrm{~mm}$

- API $120 \mathrm{mM}$

- API $60 \mathrm{mM}$

API $30 \mathrm{~mm}$

- API $15 \mathrm{mM}$

- API $7.5 \mathrm{~mm}$

API $3.75 \mathrm{~mm}$

API $0.93 \mathrm{mM}$

API $0.46 \mathrm{mM}$

API $0.23 \mathrm{mM}$

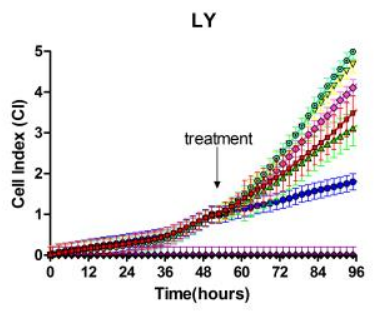

- LY $20 \mathrm{~mm}$

- LY $10 \mathrm{mM}$

- LY $5 \mathrm{mM}$

$\rightarrow$ LY $2.5 \mathrm{mM}$

- DMEM

- Control

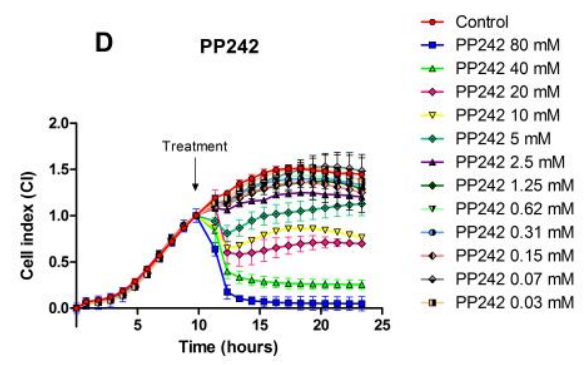

Figure 2. A. Real-time monitoring of cytotoxic effect of NVP-BEZ 235 on DLD-1 cancer cells using RTCA. B. Real-time monitoring of cytotoxic effect of API-1 on DLD-1 cancer cells using RTCA. C. Real-time monitoring of cytotoxic effect of LY294002 on DLD-1 cancer cells using RTCA. D. Real-time monitoring of cytotoxic effect of PP242 on DLD-1 cancer cells using RTCA.
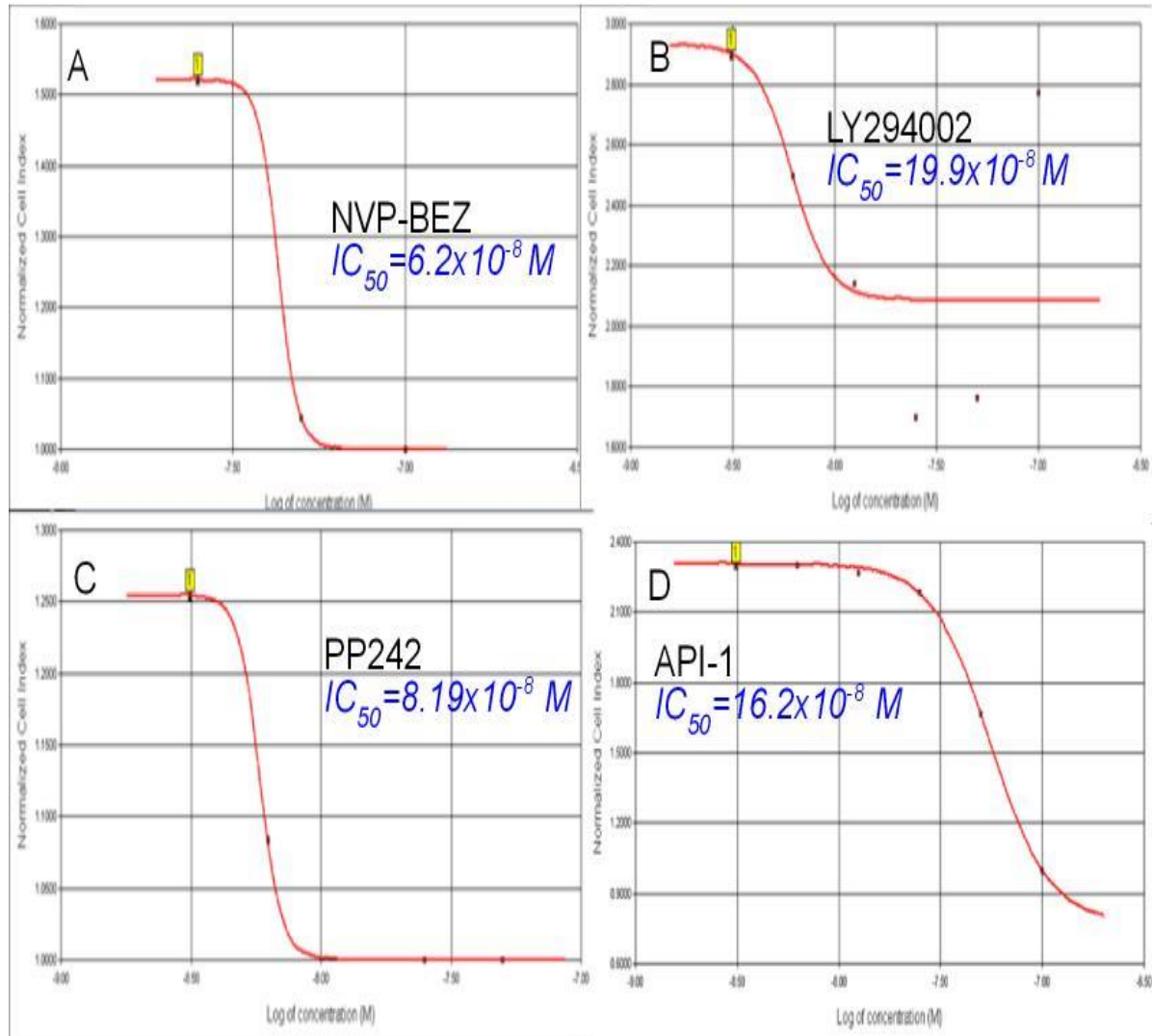

logdconerotan M

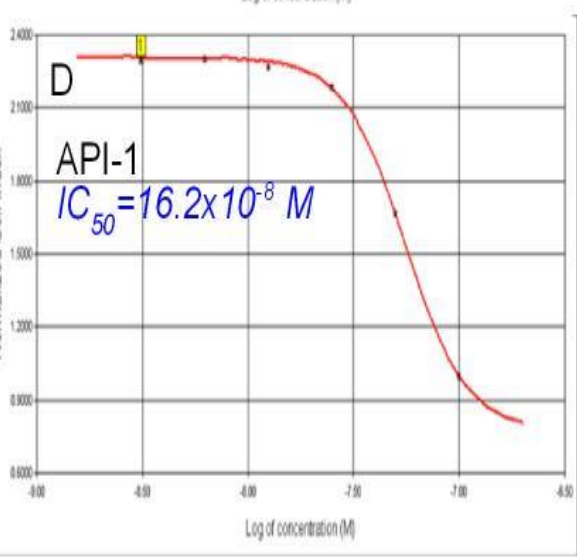

Figure 3. Calculation of IC50 values of NVP-BEZ 235, LY294002, PP242 and API-1. 


\section{Comparing the cytotoxic effect of the agents}

The inhibitor concentration 50 (IC50) values of agents used alone were used to compare the cytotoxic effects on DLD-1 colon cancer cells. It was observed that PI3K/mTOR dual inhibitor NVP-BEZ had the strongest cytotoxic effect (Figure 3A) and PI3K inhibitor LY294002 had the lowest cytotoxic effect (Figure 3B). The sequence of the agents according to IC50 values is as follows NVP-BEZ<PP242<API-1<LY294002 (Figure 4).

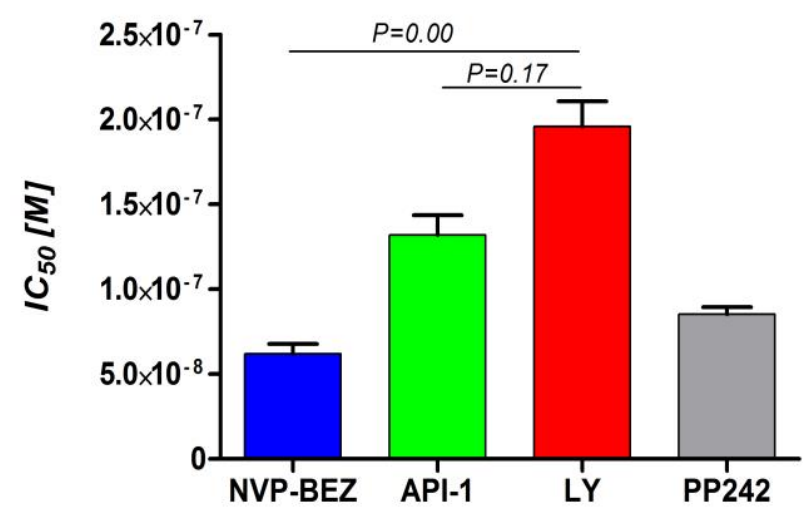

Figure 4. Comparison of the IC50 values of NVP-BEZ 235, LY294002, PP242 and API-1.

\section{Monitoring of cytotoxicity of agents in combination in real-time using xCELLigence system}

\section{NVPBEZ-235+API-1 combination}

In order to determine the anti-tumoral interaction effect between NVPBEZ-235 and API1, $62.5 \mathrm{nM}$ NVPBEZ-235 and $7.5 \mathrm{mM}$ API-1(partial effective concentrations) were combined. It was observed that there was no statistical difference between the application of NVPBEZ-235 $62.5 \mathrm{nM}+$ API-1 $7.5 \mathrm{mM}$ and alone NVPBEZ-235 $62.5 \mathrm{nM}$ and alone API-1 $7.5 \mathrm{mM}$ applications. Also to see if there is additive interaction, one agent's effective concentration was combined with the other agents' ineffective concentration (NVP $62.50 \mathrm{nM}+$ API $0.9 \mathrm{mM}$, NVP $15.63+$ API $7.5 \mathrm{mM}$ ). There was no statistical difference by using the agents alone (Figure $5 \mathrm{~A}$ ).

\section{PP242+API-1 combination}

To determine the anti-tumoral combined effect between and PP242 and API-1 which have shown antitumoral effect alone on DLD-1 colon cancer cell proliferation, $10 \mathrm{mM}$ concentration of PP242 and $7.5 \mathrm{mM}$ of API-1 (partial effective concentrations) were combined. It was observed that there was no statistical difference between the application of PP242 $10 \mathrm{mM}+$ API-1 $7.5 \mathrm{mM}$ and alone PP242 $10 \mathrm{mM}$ and alone API-1 $7.5 \mathrm{mM}$ applications. To see whether there is additive interaction, one agent's effective concentration was combined with the other agents' ineffective concentration (PP242 10 $\mathrm{mM}+\mathrm{API} 0.93 \mathrm{mM}$, PP242 1.25+API $7.5 \mathrm{mM}$ ). Also there was no statistical difference with using the agents alone (Figure 5B).

\section{PP242+NVP-BEZ combination}

To determine the anti-tumoral combined effect between and PP242 and NVP-BEZ which have shown anti-tumoral effect alone on DLD-1 colon cancer cell proliferation, $10 \mathrm{mM}$ concentration of PP242 and $62.5 \mathrm{nM}$ of NVP-BEZ (partial effective concentrations) were combined. It was observed that there was no statistical difference between the application of PP242 $10 \mathrm{mM}+$ NVP-BEZ 62.5nM and alone PP242 $10 \mathrm{mM}$ and alone NVP-BEZ 62.5 $\mathrm{nM}$ applications. One agent's effective concentration was combined with the other agents' ineffective concentration (PP242 $10 \mathrm{mM}+\mathrm{NVP} 15.63 \mathrm{nM}, \mathrm{PP} 2421.25 \mathrm{mM}+\mathrm{NVP}$ 
$62.5 \mathrm{nM}$ ) in order to see if there is addictive concentration. There was no statistical difference with using the agents alone (Figure 5C).
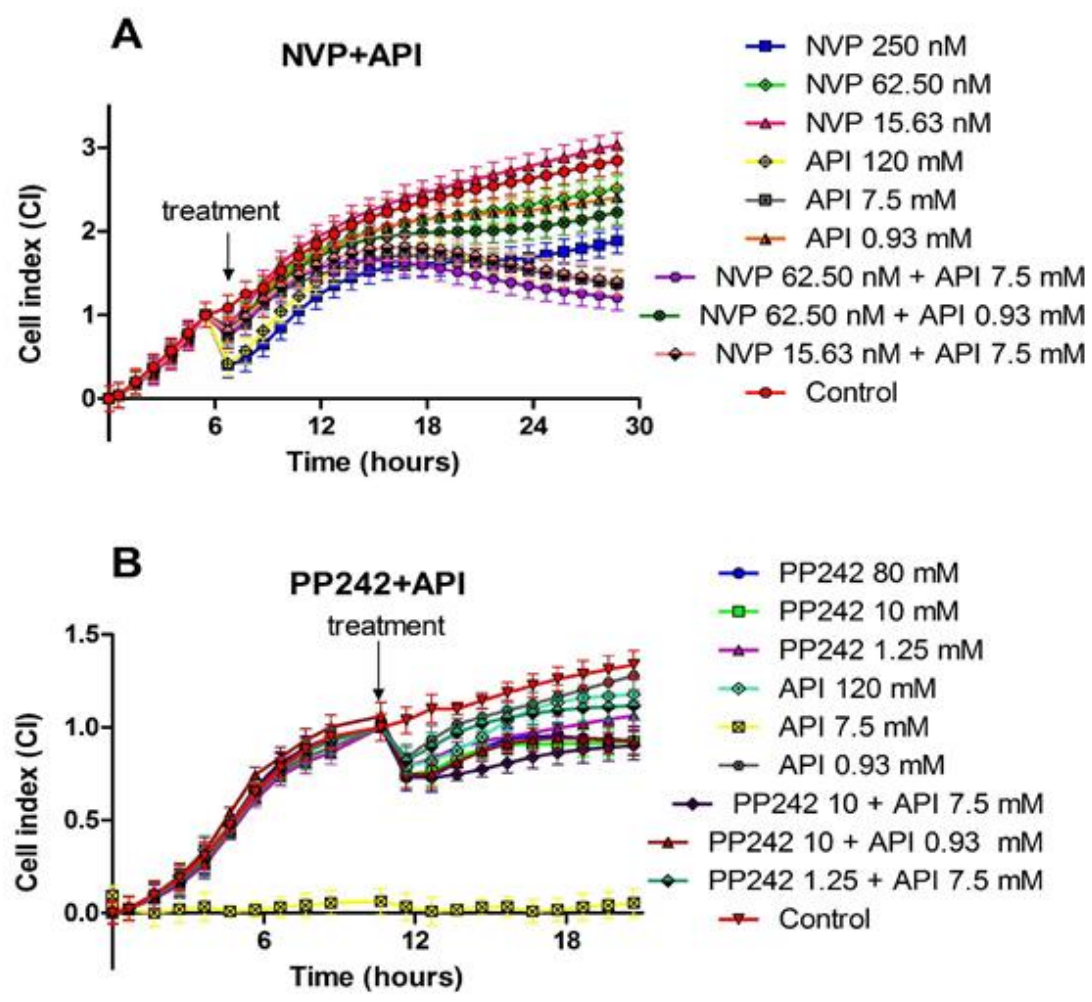

C

PP242+NVP

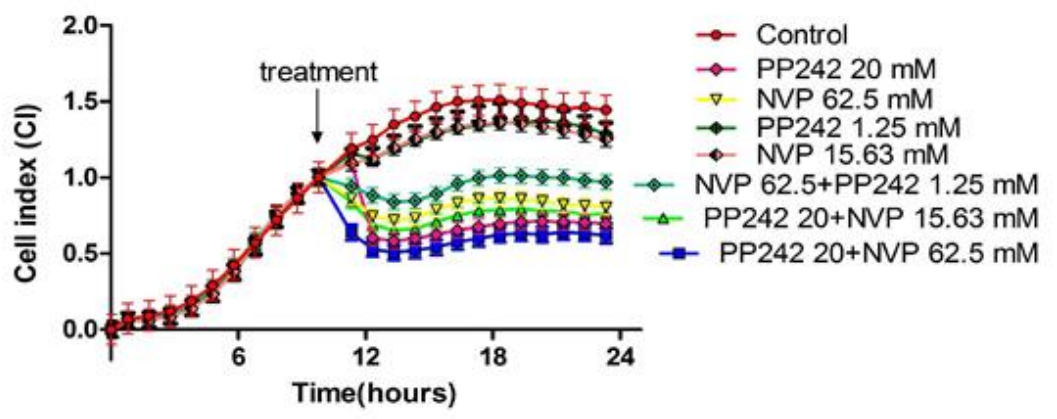

Figure 5. A; real-time monitoring of cytotoxic effect of NVP-BEZ 235 and API-1 combination on DLD-1 cancer cells using RTCA. B; real-time monitoring of cytotoxic effect of PP242 and API-1 combination on DLD-1 cancer cells using RTCA. C; real-time monitoring of cytotoxic effect of PP242 and NVP-BEZ 235 combination on DLD-1 cancer cells using RTCA. 


\section{Discussion}

Although progress in surgery, chemotherapy and radiation therapy have developed outcomes for CRC; unfortunately mortality rates continue to be high and new treatments are needed [17]. The progress of CRC is a complex process that can last several decades as sequential stages from polyps to adenocarcinoma includes multiple molecular pathways [18]. The 5 year survival rate for metastatic colon cancer is below $10 \%$. Because of this understanding cancer biology and developing new treatments is necessary. One of the signal pathway involved in CRC is PI3K/AKT pathway and $20 \%$ of patients have PIK3CA mutations [5, 6]. In this pathway, ligand binds to EGRF and this stimulates the activation of $\mathrm{PI} 3 \mathrm{~K}$ and produces phosphatidylinositol 3, 4, 5trisphosphosphate (IP3) which recruits Akt, a serine/threonine protein kinase to the cell membrane. Akt, is activated by site-specific phosphorylation at Ser473 and Thr308 and regulates proliferation and apoptosis $[19,20]$. It is also over expressed in some cancers like steroid hormone insensitive breast cancers, pancreatic, ovarian and colon cancers [21, 22]. Activation of Akt signaling has been reported in 60-70\% of human CRC [23]. It has been shown that targeted inhibition of PI3K/Akt pathway components decreases cell growth and increases apoptosis in CRCs. Also inhibiting this pathway both decreases the metastatic capability of CRCs and increases sensitivity to chemotherapy [24, 25].

Many downstream targets are regulated by Akt including mTOR which promotes angiogenesis, protein translation, growth and metabolism. It has been shown that mTOR is a direct substrate for the Akt kinase and Serine 2448 [26]. mTOR has two functionally diverse protein complexes as follows mTORC1 and mTORC2 [27]. The mTORc1 is activated by pAkt. One of the most known targets of mTORC1 is serine/threonine kinase p70S6K1 and another is 4EBP1, an inhibitory protein [28]. It has been shown that the mTORC1/mTORC2 proteins are overexpressed in CRC tissues [29]. In CRCs deregulation of mTOR pathway achieves a substantial focus [30].

Agents inhibiting PI3K/Akt pathway have been suggested as potential therapeutic agents in CRC. BYL719 (Novartis) is the first specific PI3K inhibitor. Rapamycin is a well known inhibitor of mTOR and the PI3K pathway. New agents are being developed to target PI3K, AKT and mTORC1/mTORC2. The aim of this study was twofold: 1) to investigate the effects of NVP-BEZ 235 (PI3K and mTOR inhibitor), API-1 [selective AKT/proteinkinase B(PKB) inhibitor] and PP242 (selective mTOR inhibitor) which have not been studied for CRC before by comparing with LY294002 (selective PI3K inhibitor) an agent which its' effectiveness has been shown for colon cancer $[14,15]$, and 2) also to investigate the combination effects of these agents. Therefore our objective was to determine the agent and/or possible agent combinations that may be effective in the treatment of colon cancer.

When we applied the agents alone we observed that PI3K/mTOR dual inhibitor NVPBEZ had the strongest cytotoxic effect and PI3K inhibitor LY294002 had the lowest cytotoxic effect. The sequence of the agents according to IC50 values is as follows NVPBEZ<PP242<API-1<LY294002. PI3K inhibitor LY294002 having the lowest cytotoxic effect led us to think that even though PI3K one of the first adaptor protein of the pathway is inhibited the other mediators in the pathway such as AKT and mTOR may be activated by other pathways and/or postreceptor mediator proteins. Thus although PI3K is inhibited the pathway was reactivated by a side connection and the proliferation processes were not totally but partially restored. Dual inhibitor NVP-BEZ having the strongest cytotoxic effect clearly indicates the importance of mTOR in proliferative processes. It seems as an effective cytotoxicity has been provided on colon cancer cells as mTOR is the direct activator of proliferative processes via S6 and after inhibition the pathway can not be activated by another side pathway or by a protein.

After evaluating the agents effecting PI3K/AKT pathway alone the agents were applied in combination. None of the combinations were not superior compared to alone applications. 
This result may show that this pathway up to AKT may have link with other pathways or systems and after AKT because of the pathway becoming more isolated less interference can turn on. Namely AKT and mTOR inhibition by their self can inhibit proliferative processes. In this study ineffective combinations may also be related to combining agents that aim similar downstream pathways. Therefore combining tyrosine kinase inhibitors with agents affecting another pathway that plays important role in cancer pathogenesis may compose better results.

As a result in the light of the findings of this study, we have concluded that when PI3K/AKT pathway is targeted, instead of combined treatment target specific treatment with a single agent having higher affinity and effectiveness would be more appropriate. Also for CRCs the agents effecting PI3K/AKT pathway especially, NVP-BEZ as targeted therapy can be alternative to conventional treatments. Obviously there is need for detailed studies for better illumination of the pathway and better understanding of adapter proteins acting in this pathway and also finding more specific agents to inhibit the proteins or enzymes in the critical point.

\section{References}

1. Siegel R, Ward E, Brawley O, Jemal A. Cancer statistics, 2011: The impact of eliminating socioeconomic and racial disparities on premature cancer deaths. CA Cancer J Clin 2011; 61: 212-36.

2. Kinzler KW, Vogelstein B. Lessons from hereditary colorectal cancer. Cell 1996; 87: 159-70.

3. Bachman KE, Argani P, Samuels Y. The PIK3CA gene is mutated with high frequency in human breast cancers. Cancer Biol Ther 2004; 3: 772-5.

4. Hahn WC, Weinberg RA. Rules for making human tumor cells. New Engl J Med 2002; 347: 1593-603.

5. Garcia-Echeverria C, Sellers WR. Drug discovery approaches targeting the PI3K/Akt pathway in cancer. Oncogene 2008; 27: 5511-26.

6. Huang XF, Chen JZ. Obesity, the PI3K/Akt signal pathway and colon cancer. Obes Rev 2009; 10: 610-6.

7. Zhao L, Class I. PI3K in oncogenic cellular transformation. Oncogene 2008; 27: 5486-96.

8. Cantley LC. The phosphoinositide 3-kinase pathway. Science 2002; 296:1655-7.

9. Itoh N, Semba S, Ito M. Phosphorylation of Akt/PKB is required for suppression of cancer cell apoptosis and tumor progression in human colorectal carcinoma. Cancer 2002; 94(12): 3127-34.

10. Khaleghpour K, Li Y, Banville D, Yu Z, Shen SH. Involvement of the PI 3kinase signaling pathway in progression of colon adenocarcinoma. Carcinogenesis 2004; 25: 241-8.

11. Gingras AC, Raught B and Sonenberg N. mTOR signaling to translation. Curr Topics Microbiol Immunol 2004; 15: 147-59.

12. Wullschleger S, Loewith R, Hall MN. TOR signalling in growth and metabolism. Cell 2006; 124: 471-84.

13. Johnson SM, Gulhati P, Rampy BA. Novel expression patterns of $\mathrm{PI} 3 \mathrm{~K} / \mathrm{Akt} / \mathrm{mTOR}$ signaling pathway components in colorectal cancer. J Am Coll Surg 2010; 210: 767-76.

14. Semba S, Itoh N, Ito M, Harada M, Yamakawa $M$. The in vitro and in vivo effects of 2-(4-morpholinyl)-8-phenyl-chromone (LY294002), a specific inhibitor of phosphatidylinositol 3'-kinase, in human colon cancer cells. Clin Cancer Res 2002; 8: 1957-63.

15. Mallawaaratchy DM, Mactier S, Kaufman KL, Blomfield K, Christopherson RI. The phosphoinositide 3-kinase inhibitor LY294002, decreases aminoacyl-tRNA synthetases, chaperones and glycolytic enzymes in human HT-29 colorectal cancer cells. J Proteomics 2012, 75: 1590-9. 
16. Roche Diagnostics GmbH. Introduction of the RTCA SP Instrument. RTCA SP Instrument Operator's Manuel, A. Acea Biosciences, Inc. 2008; 14-16.

17. Lieu C, Kopetz S. The SRC family of protein tyrosine kinases: A new and promising target for colorectal cancer therapy. Clin Colorectal Cancer 2010; 9: 89-94.

18. Manzano A, Perez-Segura P. Colorectal cancer chemoprevention: Is this the future of colorectal cancer prevention? Sceintific Worald Journal 2012; 327341.

19. Song G, Ouyang G, Bao S. The activation of Akt/PKB signaling pathway and cell survival. J Cell Mol Med 2005; 9: 59-71.

20. Raufman JP, Shant J, Guo CY, Roy S, Cheng K. Deoxycholyltaurine rescues human colon cancer cells from apoptosis by activating EGFR-dependent PI3K/Akt signaling. J Cell Physiol 2008, 215: 538-49.

21. Brugge J, Hung MC, Mills GB. A new mutational AKTivation in the PI3K pathway. Cancer Cell 2007; 12:104-7.

22. Roy HK, Olusola BF, Clemens DL. AKT proto-oncogene overexpression is an early event during sporadic colon carcinogenesis. Carcinogenesis 2002; 23:201-5.

23. Colakoglu T, Yildirim S, Kayaselcuk F. Clinicopathological significance of PTEN loss and the phosphoinositide 3-kinase/Akt pathway in sporadic colorectal neoplasms: Is PTEN loss predictor of local recurrence? Am J Surg 2008; 195: 719-25.

24. Rychahou PG, Murillo CA, Evers BM. Targeted RNA interference of PI3K pathway components sensitizes colon cancer cells to TNF-related apoptosisinducing ligand (TRAIL). Surgery 2005; 138: 391-7.

25. Rychahou PG, Kang J, Gulhati P. Akt2 overexpression plays a critical role in the establishment of colorectal cancer metastasis. Proc Natl Acad Sci U S A 2008; 105: 20315-20.

26. Guertin DA, Sabatini DM. Defining the role of mTOR in cancer. Cancer Cell 2007; 12: 9-22.

27. Sarbassov DD, Ali SM, Kim DH. Rictor, a novel binding partner of mTOR, defines a rapamycin-insensitive and raptor-independent pathway that regulates the cytoskeleton. Curr Biol 2004; 27; 14: 1296-303.

28. Jastrzebski K, Hannan KM, Tchoubrieva EB, Hannan RD, Pearson RB. Coordinate regulation of ribosome biogenesis and function by the ribosomal protein S6 kinase, a key mediator of mTOR function. Growth Factors 2007, 25: 209-26.

29. Gulhati P, Cai Q, Li J. Targeted inhibition of mTOR signaling inhibits tumorigenesis of colorectal cancer. Clin Cancer Res 2009; 15: 7207-16.

30. Koehl GE, Spitzner M, Ousingsawat J. Rapamycin inhibits oncogenic intestinal ion channels and neoplasia in APC (Min/+) mice. Oncogene 2010; 29: 1553-60. 